\title{
Evaluation of aerated lagoon modified with spongy support medium treating Kraft pulp mill effluent
}

\author{
Evaluación de la laguna aireada modificada con medio de soporte que trata el efluente Kraft
}

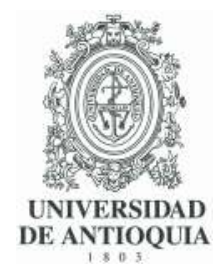

\section{Camila Peitz (10 ${ }^{1}$ Claudia Regina Xavier (1) ${ }^{1 *}$}

${ }^{1}$ Grupo GTEF, Programa de Pós-graduação em Ciência e Tecnologia Ambiental, Departamento de Química e Biologia DAQBi, Universidade Tecnológica Federal do Paraná. R. Deputado Heitor Alencar Furtado, 5000, Curitiba - PR. C.P. 81280340, Curitiba, Brasil

\section{CITE THIS ARTICLE AS:}

\section{Peitz, C. R. Xavier.} "Evaluation of aerated lagoon modified with spongy support medium treating Kraft pulp mill effluent", Revista Facultad de Ingeniería Universidad de Antioquia, no. 92, pp . 70-79, Jul-Sep 2019. [Online]. Available: https://www.doi.org/ 10.17533/udea.redin. 20190725

\section{ARTICLE INFO:}

Received: March 18, 2019 Accepted: June 07, 2019 Available online: June 07, 2019

\section{KEYWORDS:}

Biological treatment, biodegradation, specific compounds

Tratamiento biológico, biodegradación, compuestos específicos
ABSTRACT: The pulp industry generates high effluent flows, which contain high chemical oxygen demand (COD), biochemical oxygen demand $\left(\mathrm{BOD}_{5}\right)$, colour and ecotoxicity. This study aimed to evaluate the treatment of Kraft pulp effluent by aerated lagoon modified with sponge support media (APG). It was assessed the arrangement of the support media in the aerated lagoons in the organic load rate (OLR) of $0.2 \mathrm{~kg}_{\mathrm{coD}} \mathrm{m}^{-3} \mathrm{~d}^{-1}$, and after that, with OLR variation from 0.2 to $1.2 \mathrm{~kg}_{\mathrm{COD}} \mathrm{m}^{-3} \mathrm{~d}^{-1}$. The parameters evaluated were $\mathrm{BOD}_{5}, \mathrm{COD}$, colour, lignin derivatives, total phenolic compounds and acute ecotoxicity in D. magna. COD and $\mathrm{BOD}_{5}$ removals were $32 \%$ and $88 \%$, respectively, for free and confined support media in $0.2 \mathrm{~kg}_{\mathrm{COD}} \mathrm{m}^{-3} \mathrm{~d}^{-1}$. There was no colour or total phenolic compounds removal under these conditions. Considering the treatment in which there was a variation of the organic load rate, $1.2 \mathrm{~kg}_{\mathrm{COD}} \mathrm{m}^{-3} \mathrm{~d}^{-1}$ had the best performance. In this case, $50 \%$ and $75 \%$ of $\mathrm{COD}$ and $\mathrm{BOD}_{5}$ were removed, respectively. Removal of colour, total phenolic compounds and lignin derivatives were around $20 \%, 18 \%$ and $10 \%$, respectively. The acute ecotoxicity was reduced to toxicity factor equal to 1 in all treatments. Comparing the aerated lagoon modified systems with those without the APG, it was suggested to apply spongy support in higher organic load rate than these typically used in aerated lagoons.

RESUMEN: La industria de celulosa genera grandes flujos de efluentes que contienen una alta demanda química de oxígeno (DQ0), demanda bioquímica de oxígeno $\left(\mathrm{DBO}_{5}\right)$, color y ecotoxicidad. Este estudio tuvo como objetivo evaluar el tratamiento del efluente de celulosa Kraft en lagunas aireadas con medios de soporte de esponja (APG). Fue evaluado el arreglo de los medios de soporte en carga orgánica volumétrica de $0,2 \mathrm{~kg}_{\mathrm{DQO}} \mathrm{m}^{-3}$ $\mathrm{d}^{-1}$, después de esto se estudió una variación de carga de 0,2 a $1,2 \mathrm{~kg}_{\mathrm{DQO}} \mathrm{m}^{-3} \mathrm{~d}^{-1}$. Se evaluaron los parámetros $\mathrm{DBO}_{5}, \mathrm{DQO}$, color, derivados de lignina, compuestos fenólicos totales y ecotoxicidad en $D$. magna. Las remociones de $\mathrm{DQO}$ y $\mathrm{DBO}_{5}$ fueron de $32 \%$ y $88 \%$, respectivamente, para los medios de soporte libres y confinados en $0,2 \mathrm{~kg}_{\mathrm{DQO}} \mathrm{m}^{-3} \mathrm{~d}^{-1}$. No hubo remoción del color o compuestos fenólicos totales en estas condiciones. Considerando la variación de la carga orgánica volumétrica, el mejor desempeño fue para $1,2 \mathrm{~kg}_{\mathrm{DQO}} \mathrm{m}^{-3}$ $\mathrm{d}^{-1}$, donde fueron eliminados $50 \%$ y $75 \%$ de la $\mathrm{DQO}$ y $\mathrm{DBO}_{5}$, respectivamente. La remoción del color, compuestos fenólicos totales y derivados de lignina fueron de cerca de $20 \%, 18 \%$ y $10 \%$, respectivamente. La ecotoxicidad aguda se redujo a factor de toxicidad de 1 en todos los tratamientos. Comparando los sistemas de laguna aireada sin la presencia del APG, se sugiere aplicar un soporte esponjoso en carga orgánica más alta que aquellas típicas de lagunas aireadas.

\section{Introduction}

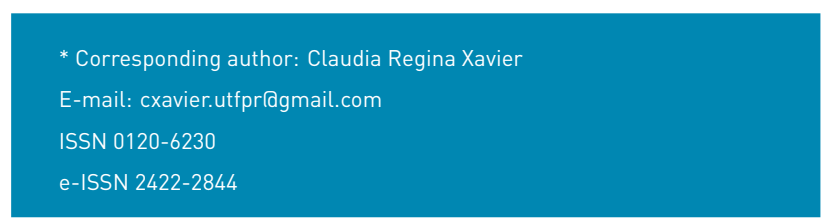

Among the characteristics of pulp and paper industry, there is a consumption of more than $40 \mathrm{~m}^{3}$ of water per ton of produced pulp and, consequently, large amounts of effluents are generated. In general, this effluent is rich in organic matter, suspended solids, resin acids, lignin 
derivatives, colour and ecotoxicity [1].

The developed systems to treat pulp mill effluent have the objective to remove organic matter, colour and ecotoxicity. Aerated biological treatments, such as activated sludge and aerated lagoons, are the most used [2]. Aerated lagoons have simple maintenance and low cost when compared with other systems such as IFAS (Integrated-fixed Film Activated Sludge) and activated sludges [3]. They are considered stable to load shocks, distributing the excess in its extension, in addition to showing high retention times (2 to 10 days) [3, 4]. They are the most used in the treatment of effluents from the pulp industry [3].

Another biological treatment stable to load shocks is the MBBR (Moving Bed Biofilm Reactor), which uses hydraulic retention times of 3 to 48 hours [5]. This biological treatment system uses support media to provide adhesion surface for microbial biomass, allowing the contact with the substrates in the reactor mixed liquor $[5,6]$.

The support media applied in this type of biological treatment are generally made of high density polyethylene or polypropylene. They are inert and have a high specific surface area (>1000 $\left.\mathrm{m}^{2} \mathrm{~m}^{-3}\right)$ [7].

For the choice of support media, the best adhesion of the microorganisms is desired, besides high mechanical strength and low cost. Properties such as surface area, porosity, roughness, particle diameter, density and filling ratio of the reactor affect the adhesion dynamics of the microorganisms, influencing the treatment efficiency $[8,9]$.

There is a wide variety of support media for moving bed systems. Among them, there is AQUAPOROUSGEL ${ }^{\circledR}$ (APG) from Nisshinbo Chemical Inc.. The APG is cubic in shape with specific surface area greater than $3000 \mathrm{~m}^{2}$ $\mathrm{m}^{-3}$, specific mass of $30 \mathrm{dry} \mathrm{kg} /$ wet $^{3} \mathrm{~m}^{3}$, multiporous and its material is based on polyethylene-glycol [10]. It has a high resistance to abrasion, absorbing water and providing a hydrophilic surface for the bacteria to settle and colonize. According to the manufacturer, the filling ratio for efficient treatment is $10 \%$ of the reactor volume, a value lower than other support medias, which are in the range of 25 to $70 \%$ $[8,11]$.

These systems, aerated lagoons and moving bed biofilm reactor, can achieve 20 to $70 \%$ COD removal; however, they have low removals of recalcitrant compounds derived from lignin and phenolic compounds $[12,13]$.

Currently, ecotoxicological tests are also needed to properly assess the quality of the effluent for the correct disposal in water bodies. In these analyses, the test-organisms are exposed to different sample concentrations and the effects produced on them are observed and assessed. Among the most used organisms, we have the microcrustacean Daphnia magna $[14,15]$.

Therefore, this paper aimed to evaluate the arrangement of support media and the influence of organic loading variation applied in aerated lagoons modified with spongy support medium to treat Kraft pulp effluent.

\section{Materials and methods}

The effluent used for the treatment was gently obtained by an industry of unbleached Kraft pulp in Curitiba region, Brazil. The effluent was collected before biological treatment, after grating, transported and stored at $4^{\circ} \mathrm{C}$ protected from light in gallons of $20 \mathrm{~L}$.

The continuous treatment occurred in an aerated lagoon, in lab scale, with $1 \mathrm{~L}$ of volume, filled with $10 \%$ of spongy support AQUAPOROUSGEL ${ }^{\circledR}$ (APG) (Figure 1).

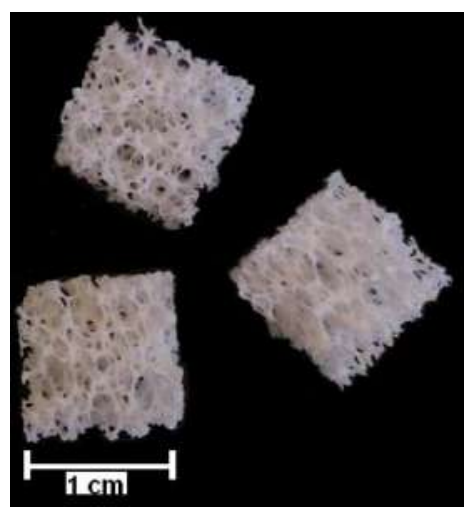

Figure 1 Spongy support AQUAPOROUSGEL ${ }^{\circledR}$ (APG)

To evaluate the arrangement effect of the support media, they were either used free $(A L(A))$ in the aeration zone or confined in plastic crates (AL(B)) (Figure 2), both in the organic loading rate $0.2 \mathrm{~kg}_{\mathrm{CoD}} \mathrm{m}^{-3} \mathrm{~d}^{-1}$. To assess the influence of organic loading rate (OLR) variation applied to the aerated lagoon with media support (AL-APG), loadings of 0.2 without media support; $0.2 ; 0.6$ and $1.2 \mathrm{~kg}_{\mathrm{CoD}} \mathrm{m}^{-3} \mathrm{~d}^{-1}$ with confined spongy support were used. Load changes were performed when the system reached a steady state, with removal variation of up to $10 \%$.

Aeration was promoted by air pumps to maintain the support media in movement and the concentration of dissolved oxygen above $4.0 \mathrm{mg} \mathrm{L}^{-1}$, this parameter was monitored, once a week, by a Lutron D0-5519 oximeter. The APG (AQUAPOROUSGEL ${ }^{\circledR}$ ) spongy support used during biological treatment was gently provided by 


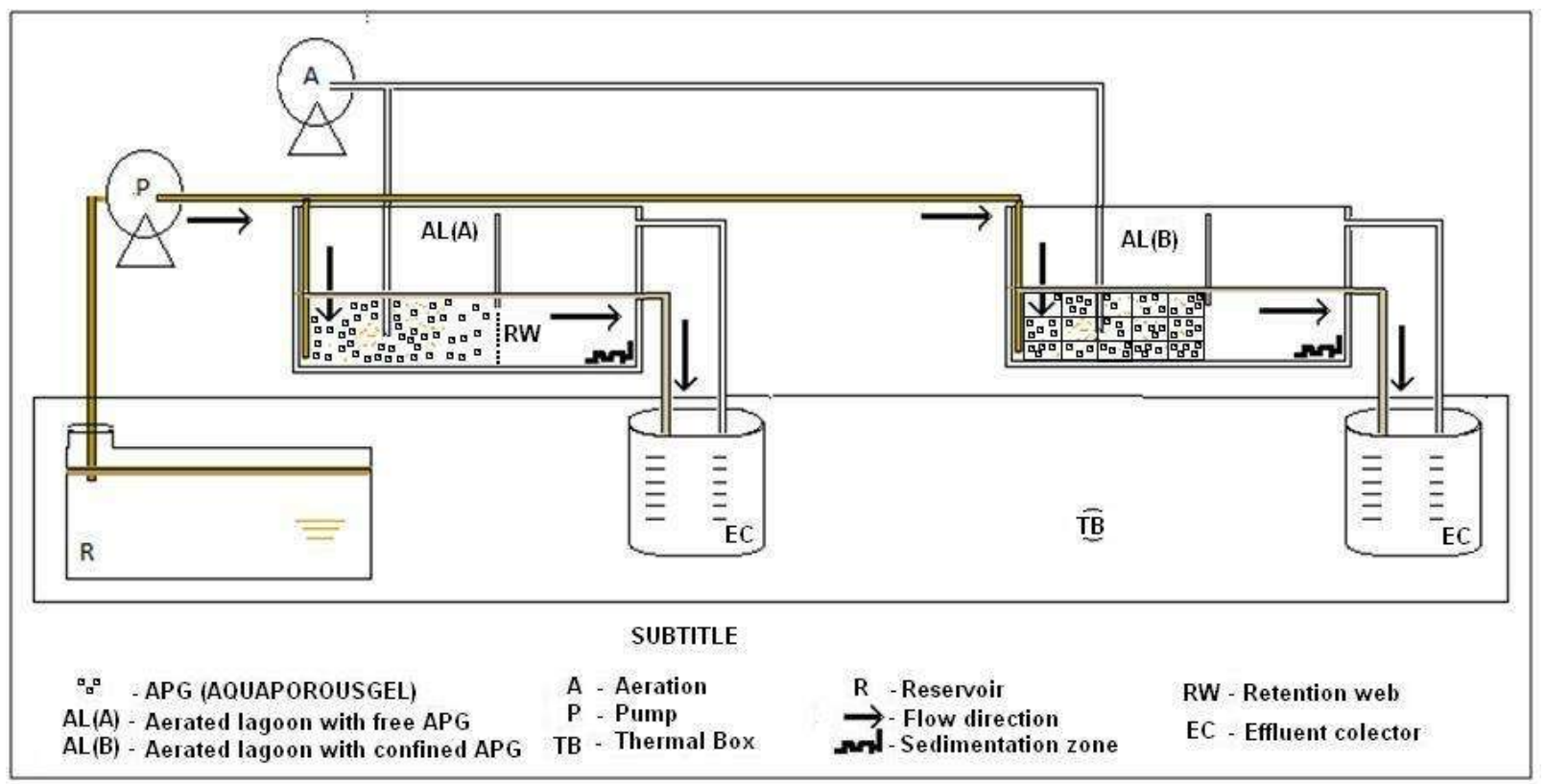

Figure 2 Aerated lagoon in lab scale. Source: Adapted from [13]

Nisshinbo Chemical Inc.

The sludge used was purchased from the bottom of an aerated lagoon of an unbleached pulp industry in Curitiba region - Brazil, with a final concentration of $70 \mathrm{mgVSS} \mathrm{L}^{-1}$ in each system. To assess the support media arrangement, both systems started without sludge inoculation, based on other studies of the authors no showed in this article, with MBBR, in which inoculations were not made [16]. After 32 days of operation, both aerated lagoons were inoculated for concentrations at 70 mgVSS $L^{-1}$ due to the non-visible growth of suspended and adhered solids up in mixed liquor to moment [17]. To assess the variation of organic loading rate, the inoculation was made at the start of the aerated lagoon, still without the presence of spongy support.

The analytical parameters were: Biochemical Oxygen Demand $-\mathrm{BOD}_{5}$ and Chemical Oxygen Demand - COD [18]; Total Phenolic Compounds - TPC $\left(U_{215 n m}\right)$, colour $\left(V_{i s}{ }_{440 \mathrm{~nm}}\right)$, aromatic compounds $\left(U V_{254 n m}\right)$, lignin derived compounds $\left(\mathrm{UV}_{280 \mathrm{~nm}}\right)$ and lignosulfonic acid $\left(\mathrm{UV}_{346 \mathrm{~nm}}\right)$ $[19,20]$, in samples filtered with nitrocellulose membrane of $0.45 \mu \mathrm{m}$ porosity, which were monitored during continuous biological treatment.

For the acute ecotoxicity assays with $D$. magna, the samples were obtained by aerated lagoon treatment with spongy support (AL-APG). The acute effect was estimated based on $\mathrm{EC}_{50}$ in 48 hours of exposure, obtained and converted to Toxicity Factor (TF), which is the unit that represents how many times the receiving body would need to dilute the effluent that it ceases to be toxic to the organisms present in the water bodies. The higher this value, the greater the ecotoxicity [21].

Adhered solids were considered as the biofilm formed in the spongy support during biological treatment by modified aerated lagoons. The biofilm adhered to the spongy carrier was quantified by suitability of the method section 2540 D, E and F from Standard Methods for the Examination of Water and Wastewater of the American Public Health Association (APHA), 2012, in which the APG samples were subjected to a $50 \mathrm{~mL}$ volume ultrasonic bath in deionized water for one (1) hour, being sequentially conducted according to the same method. Suspended solids were considered as the biomass present in the mixed liquor. Analyzes were done according to section $2540 \mathrm{D}, \mathrm{E}$ and $\mathrm{F}$ Standard Methods for the Examination of Water and Wastewater of the American Public Health Association (APHA), 2012. Both determinations were performed in triplicate during the steady state of each applied organic load rate and the results were expressed as $\mathrm{mg} \mathrm{L}^{-1}[18]$.

The data obtained during the treatment by aerated lagoons modified with the addition of spongy support were evaluated by ANOVA and Tukey post-test in the program of UFSCar's Center of Agricultural Sciences after verification of their normality, with significance level $p<0.05$ and with the hypothesis of presenting a significant difference between the systems and their organic load rate in comparison to the removal of the physicochemical parameters evaluated [22]. 


\section{Results and discussions}

\subsection{Arrangement of Spongy Support}

Three effluent samples were collected in the industry of unbleached pulp for 89 days of operation of aerated lagoons (AL - APG) in continuous treatment, related to the duration of the samples during treatment. The characterization of each sample is shown on Table 1.

Sample 1, used between days 1 and 32 of the treatment by aerated lagoons and $\mathrm{HRT}$ of $1.35 \mathrm{~d}$, showed a $\mathrm{BOD}_{5} / \mathrm{COD}$ ratio favorable to the biological treatment $(0.35)[12,13]$. Sample 1 had total phenolic compounds concentration higher than $230 \mathrm{mg} \mathrm{L}^{-1}$, which was considered high according to other studies with in this subject $[12,13,19]$. Sample 2, used between days 33 and 69 and HRT 1.95 d, showed a $\mathrm{BOD}_{5} / \mathrm{COD}$ ratio below 0.2 , and total phenolic compound concentrations near $400 \mathrm{mg} \mathrm{L}^{-1}$, indicating an effluent less conducive to biological treatments [19]. Sample 3, used between days 70 and 89 and HRT $1.85 \mathrm{~d}$, also showed a better profile for biological treatment, with $\mathrm{BOD}_{5} / \mathrm{COD}$ ratio of 0.33 and with the lowest TPC concentration (113 $\mathrm{mg} \mathrm{L}^{-1}$ ) [16]. In general, the characteristics of different samples agree with those found by different authors, corroborating the variety that a real sample of the industry can present $[13,16,19,23]$.

Figure 3 shows the AL-APG performance in the free (AL(A)) and confined (AL(B)) modalities during the 89 days of operation, where the load varied from $(0.23 \pm 0.07)$ $\mathrm{kg}_{\mathrm{COD}} \mathrm{m}^{-3} \mathrm{~d}^{-1}$.

Additionally, removals of organic matter from 8 to $32 \%$ were observed for COD, where AL(A) system showed a better performance on average. In sample 1, the AL(A) and $A L(B)$ systems provided removals between 15 and $28 \%$. In sample 2 (more recalcitrant and harder to treat biologically), COD removal decreased to less than $20 \%$. Both samples 1 and 2 had lower removal of COD than the obtained in another aerated lagoon (50\%) [13]. For sample 3, COD removal reached (20-43\%) which were close to other studies (30-40\%) treating pulp mill effluent in full scale aerated lagoon [24]. Dykstra et al. (2015), treated pulp mill effluent in aerated lagoon at the OLR $0.15 \mathrm{~kg}_{\mathrm{COD}} \mathrm{m}^{-3} \mathrm{~d}^{-1}$ and Belmonte et al. (2006) treated pulp mill effluent by aerated lagoon at OLR of $0.6 \mathrm{~kg}_{\mathrm{COD}} \mathrm{m}^{-3} \mathrm{~d}^{-1}$. obtaining removals above $60 \%$ and Machado et al. (2018), average $52 \%$ removal of $\mathrm{COD}$ in facultative aerated lagoon employing $0.2 \mathrm{~kg}_{\mathrm{COD}} \mathrm{m}^{-3} \mathrm{~d}^{-1}$ in the treatment of Kraft pulp mill effluent in the absence spongy support [13, 24-26].

The average values of $\mathrm{BOD}_{5}$ removal, for both studied lagoons, were between 59 and $88 \%$, within the expected for aerated lagoon systems treating effluents from paper and pulp industries, where in these systems the $\mathrm{BOD}_{5}$ removals can vary from 50 to $90 \%$ in effluent from paper and pulp $[4,13]$. It can be observed that in both AL-APG systems, the removal of organic matter was affected by the biodegradability, which decreased $60 \%$ between sample 1 (0.35) and sample $2(0.14)$.

According to Figure 3, in general, there was an increase in colour after the treatment, except when sample 1 was used. In this case, there were removals of 28 and $32 \%$ in lagoons $A L(A)$ and $A L(B)$, respectively. Still, in both systems, the increase in colour was inferior to other ALs, in which colour increased $90 \%$ in HRT of 28 days [27]. This has been related to the polycondensation-adsorption of lignin structures, which would occur simultaneously with a mechanism of filterable colour formation due to the biochemical oxidation of some functional groups of lignin [28]. Other authors have argued that, during treatment, the organic matter that is not removed through biodegradation can be modified for chromophoric units instead of mineralized and, consequently, leads to an increase in the level of colour $[20,29]$.

Regarding total phenolic compounds, in sample 1 , less than $30 \%$ removals of the phenolic compounds were observed in the aerated lagoon with spongy support. In sample 2, where the influent already had a high concentration of total phenolic compounds $\left(\sim 400 \mathrm{mg} \mathrm{L}^{-1}\right)$, the increase in TPC was less than 10\%; however, in the treated effluents total phenolic compounds concentrations were close to $500 \mathrm{mg} \mathrm{L}^{-1}$. In sample 3, in which influent with higher biodegradability was treated, the increase in TPC reached values higher than $100 \%$, indicating possible desorption of phenolic compounds previously adhered to the support media or the sludge. TPC have also been attributed to the biotransformation of lignin derivatives, generating compounds with phenol groups [30].

During the treatment, the removal of these compounds was observed in the $A L(A)$ and $A L(B)$ systems only in sample 1 , in the others there was an increase of about $10 \%$. This increase in lignin-derived compounds was possibly related to the breakdown of high molecular weight molecules by repolymerizing them and forming new lignin-derived compounds during biological treatment by aerated lagoons $[28,30]$.

Values of the $U V_{254 \mathrm{~nm}} / U_{280 \mathrm{~nm}}$ ratio indicated higher amounts of lignin compounds $\left(U_{280 \mathrm{~nm}}\right)$ in all samples compared to the aromatic compounds $\left(U_{254 \mathrm{~nm}}\right)$ [31]. In samples 1 and 2 and their effluents generated during treatment by AL-APG, values lower than 0.6 were reached, indicating predominance of lignin compounds. 
Table 1 Characterization of Kraft effluent samples before biological treatment

\begin{tabular}{llll}
\hline Parameters & Sample 1 & Sample 2 & Sample 3 \\
\hline $\mathrm{COD}\left(\mathrm{mg} \mathrm{L}^{-1}\right)$ & $313 \pm 78.9$ & $538 \pm 24.1$ & $338 \pm 65.3$ \\
$\mathrm{BOD}_{5}\left(\mathrm{mg} \mathrm{L}^{-1}\right)$ & $104 \pm 10.3$ & $76.5 \pm 10.2$ & $110 \pm 6.91$ \\
$\mathrm{BOD}_{5} / \mathrm{COD}$ & 0.35 & 0.14 & 0.33 \\
$\mathrm{TPC}\left(\mathrm{mg} \mathrm{L}^{-1}\right)$ & $233 \pm 145$ & $397 \pm 88$ & $113 \pm 35$ \\
Colour $\left(V^{4} \mathrm{~s}_{40 \mathrm{~nm}}\right)(1 \mathrm{~cm} \times 1 \mathrm{~cm})$ & $5.39 \pm 1.80$ & $1.26 \pm 0.28$ & $0.24 \pm 0.04$ \\
Aromatic compounds $\left(\mathrm{UV}_{254 \mathrm{~nm}}\right)(1 \mathrm{~cm} \times 1 \mathrm{~cm})$ & $1.92 \pm 0.09$ & $4.64 \pm 0.14$ & $3.05 \pm 0.34$ \\
Lignin derived compounds $\left(\mathrm{UV}_{280 \mathrm{~nm}}\right)(1 \mathrm{~cm} \times 1 \mathrm{~cm})$ & $0.20 \pm 0.07$ & $1.64 \pm 0.15$ & $1.01 \pm 0.16$ \\
Lignosulfonic compounds $\left(\mathrm{UV}_{346 \mathrm{~nm}}\right)(1 \mathrm{~cm} \times 1 \mathrm{~cm})$ & $5.41 \pm 1.96$ & $8.43 \pm 1.12$ & $2.87 \pm 0.30$ \\
$\mathrm{UV}_{254 \mathrm{~nm}} / \mathrm{UV}_{280 \mathrm{~nm}}$ & 0.35 & 0.55 & 1.06 \\
\hline
\end{tabular}

In sample 3, both for the influent and the effluent of both aerated lagoons, the values obtained were between 1.10 1.20, close to those measured by Cecen (2003) (1.10-1.13), indicating lower content of lignin compounds and higher content of aromatic compounds. Since these recalcitrant structures were little altered in $A L(A)$ or $A L(B)$ treatment, which is in agreement with other studies with cellulose effluent in aerated lagoons [31].

About the acute ecotoxicity, it was observed TF equal to 2 only in sample 2, corresponding to the $A L(A)$ and $A L(B)$ influent, which had the highest concentration of TPC.

After the biological treatment in the load $0.2 \mathrm{~kg}_{\mathrm{COD}} \mathrm{m}^{-3}$ $\mathrm{d}^{-1}$, the ecotoxicological effect was of $T F=1$ in all effluent samples. It was verified a correlation between total phenolic compounds and acute toxicity, that means, the higher the concentration of TPC the higher the acute ecotoxicological effects, corroborating with the results obtained in sample 2 , with a concentration of TPC greater than $400 \mathrm{mg} \mathrm{L}^{-1}$ [32].

Analyzing the biomass results, this was preferentially concentrated in the mixed liquor. VSS concentrations of 468 and $570 \mathrm{mg} \mathrm{L}^{-1}$ were reached in the load of 0.2 $\mathrm{kg}_{\text {COD }} \mathrm{m}^{-3} \mathrm{~d}^{-1}$, where inoculation had been performed on the $32^{\text {th }}$ day of operation. Regarding the VSS/TSS ratio, values of 0.34 and 0.40 were obtained for $A L(A)$ and $A L(B)$, respectively, indicating a stabilized sludge [17].

In order to evaluate the similarities of the results, ANOVA - Tukey statistical analysis was performed after verification of data normality (Table 2).

No significant difference was observed between the $A L$ - APG systems on free and confined modalities in all physicochemical parameters evaluated during the 89 days of reactor operation, as presented on Table 2.

Comparing with the aerated lagoon control of Machado et al. (2018), that had the same organic volumetric load and similar characteristics, only in the increase of TPC and in the removal of $\mathrm{BOD}_{5}$ no differences were verified in the other parameters. This difference concludes that the aerated lagoon control presented a better removal performance of the most difficult recalcitrant compounds such as COD, colour and lignin compounds. The addition of support media in aerated lagoons at low organic load rates, such as the one studied in this paper, is not recommended, as it was seen that the removals were not improved compared with the control system [13].

Since no significant differences were observed between $A L(A)$ and $A L(B)$, the next stage was to assess the increase performance load (OLR), the layout of the confined $A L$ - APG system was chosen, because it was easier for maintenance in an industry plant.

\subsection{Treatment with Variation of Organic Loading Rate}

In this stage, the study was carried out applying the organic volumetric loads $0.2 ; 0.6$ and $1.2 \mathrm{~kg}_{\mathrm{coD}} \mathrm{m}^{-3} \mathrm{~d}^{-1}$. The performance was evaluated in the aerated lagoon with addition of spongy support, APG, in the confined mode.

The starting of $A L$ without spongy support and inoculated with $70 \mathrm{mgVSS} \mathrm{L}^{-1}$, was given in the OLR $0.2 \mathrm{~kg}_{\mathrm{coD}} \mathrm{m}^{-3} \mathrm{~d}^{-1}$ and was also maintained until reaching steady state 11 18 days of operation). After this time spongy support was added and the organic load rates were increased upon new steady state. The characterization of the used samples, during the 61 days of operation at this stage, is shown in Table 3.

Sample 4 showed a good $\mathrm{BOD}_{5} / \mathrm{COD}$ ratio (>0.3) for the biological treatment by aerated lagoon and low TPC concentration (<100 $\mathrm{mg} \mathrm{L}^{-1}$ ). In addition, it had low colour and high content of aromatic compounds as well as other pulp and paper effluents [19].

Sample 5 showed a lower $\mathrm{BOD}_{5} / \mathrm{COD}$ ratio (0.16), with high concentrations of TPC (>340 $\left.\mathrm{mg} \mathrm{L}^{-1}\right)$, colour and 


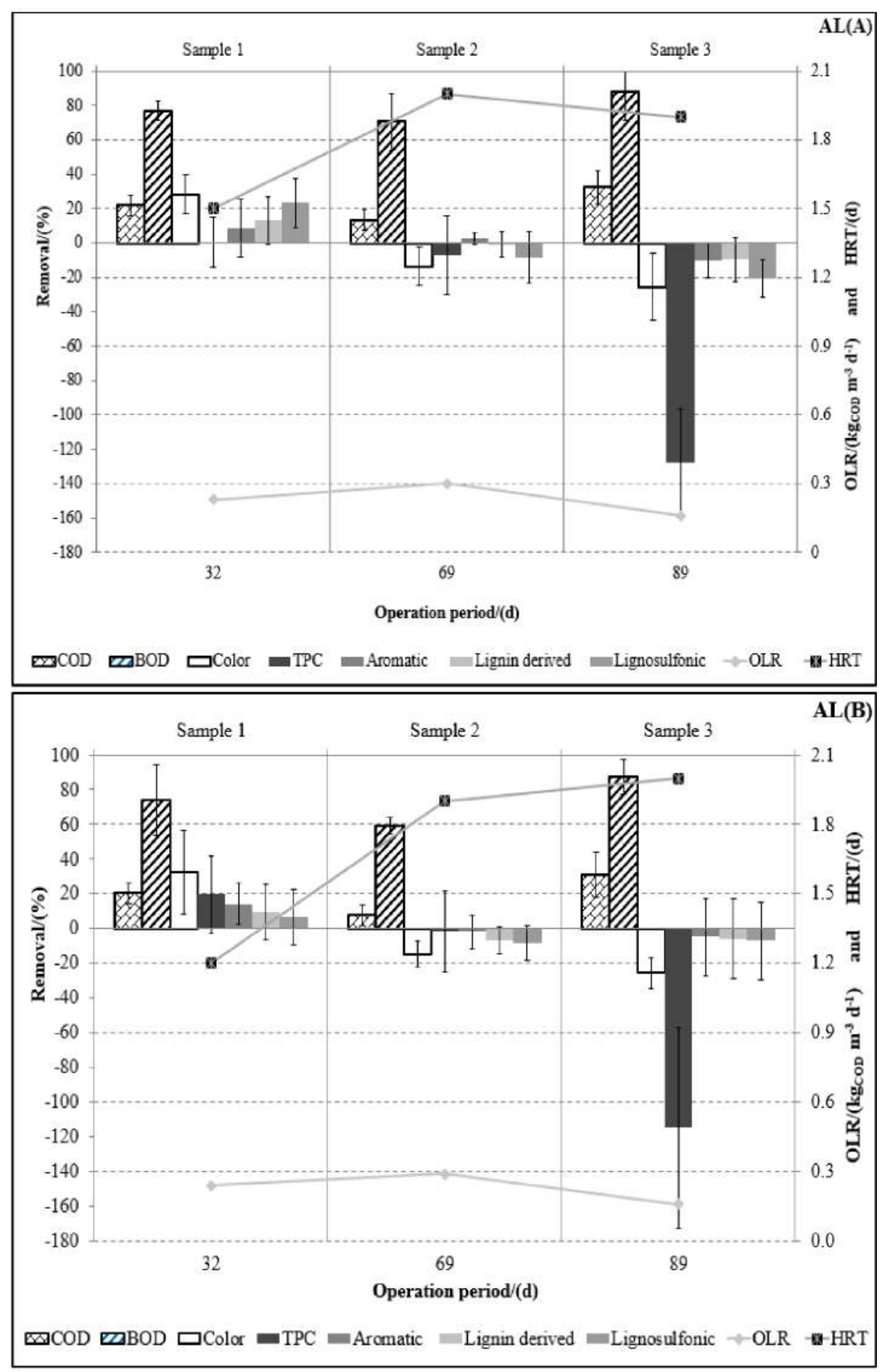

Figure 3 Removal efficiency for the different parameters and organic loading applied to free (AL(A)) and confined (AL(B)) aerated lagoon with spongy support

compounds derived from lignin, having more recalcitrant features.

In general, the characteristics in samples 4 and 5 agree with what was found by different authors, and the variations perceived between them are typical of industrial plants of paper and pulp production [25].

Figure 4 shows $A L-A P G$ performance in the confined modality during 61 days of operation, where loading varied from 0.2 to $1.2 \mathrm{~kg}_{\mathrm{COD}} \mathrm{m}^{-3} \mathrm{~d}^{-1}$. 
Table 2 Comparison of average ANOVA - Tukey* of aerated lagoon with spongy support

\begin{tabular}{|c|c|c|c|c|c|c|c|}
\hline \multirow{2}{*}{$\begin{array}{l}\text { Aerated } \\
\text { lagoon }\end{array}$} & \multicolumn{7}{|c|}{ Parameters physical-chemical } \\
\hline & COD & $\mathrm{BOD}_{5}$ & Colour & TPC & $\begin{array}{l}\text { Lignin derived } \\
\text { compounds }\end{array}$ & $\begin{array}{l}\text { Aromatics } \\
\text { compounds }\end{array}$ & $\begin{array}{l}\text { Lignosulfonic } \\
\text { compounds }\end{array}$ \\
\hline $\mathrm{AL}(\mathrm{A})$ & $21.87 \mathrm{a}$ & $76.6 \mathrm{a}$ & $-2.99 a$ & $-52.5 a$ & $1.7 \mathrm{a}$ & $1.7 \mathrm{a}$ & $0.6 \mathrm{a}$ \\
\hline$A L(B)$ & $19.60 \mathrm{a}$ & $84.4 \mathrm{a}$ & $-13.55 a$ & $-38.5 a$ & $-3.5 a$ & $0.5 \mathrm{a}$ & $-3.1 \mathrm{a}$ \\
\hline
\end{tabular}

Table 3 Characterization of Kraft effluent used in the treatment by aerated lagoon with confined APG

\begin{tabular}{|c|c|c|}
\hline Parameters & Sample 4 & Sample 5 \\
\hline $\mathrm{COD}\left(\mathrm{mg} \mathrm{L}^{-1}\right)$ & $319 \pm 77.6$ & $723 \pm 35.5$ \\
\hline $\mathrm{BOD}_{5}\left(\mathrm{mg} \mathrm{L}^{-1}\right)$ & $153 \pm 82.6$ & $106 \pm 27$ \\
\hline $\mathrm{BOD}_{5} / \mathrm{COD}$ & 0.48 & 0.16 \\
\hline $\mathrm{TPC}\left(\mathrm{mg} \mathrm{L}^{-1}\right)$ & $97.2 \pm 7.5$ & $346 \pm 32.4$ \\
\hline Colour $\left(V_{i s} 440 \mathrm{~nm}\right)(1 \mathrm{~cm} \times 1 \mathrm{~cm})$ & $0.18 \pm 0.02$ & $0.66 \pm 0.02$ \\
\hline Aromatic compounds $\left(\mathrm{UV}_{254 \mathrm{~nm}}\right)(1 \mathrm{~cm} \times 1 \mathrm{~cm})$ & $2.13 \pm 0.17$ & $7.65 \pm 1.01$ \\
\hline Lignin derived compounds $\left(U_{280 \mathrm{~nm}}\right)(1 \mathrm{~cm} \times 1 \mathrm{~cm})$ & $1.72 \pm 0.13$ & $6.87 \pm 0.54$ \\
\hline Lignosulfonic compounds $\left(U V_{346 \mathrm{~nm}}\right)(1 \mathrm{~cm} \times 1 \mathrm{~cm})$ & $0.64 \pm 0.06$ & $2.27 \pm 0.21$ \\
\hline $\mathrm{UV}_{254 \mathrm{~nm}} / \mathrm{UV}_{280 \mathrm{~nm}}$ & 1.24 & 1.18 \\
\hline
\end{tabular}

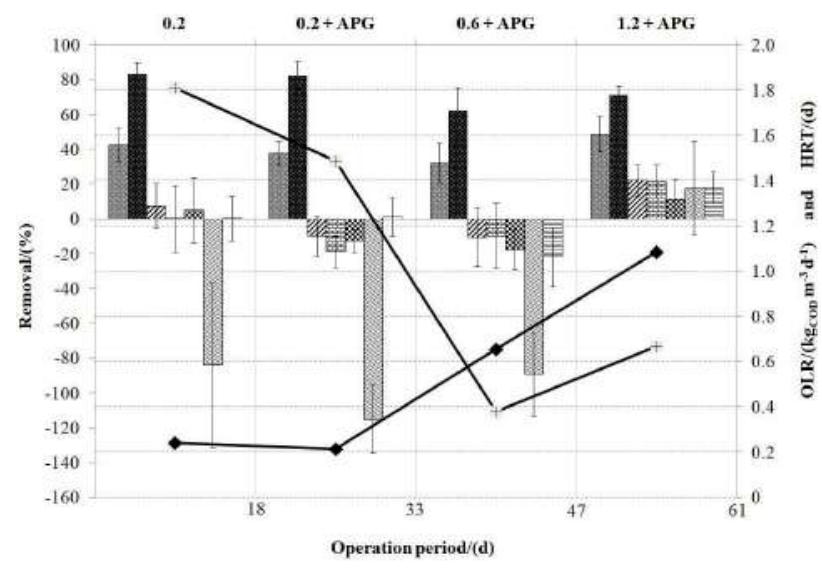

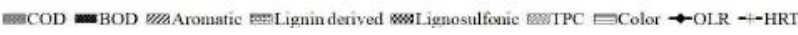

Figure 4 Efficiency of confined AL-APG system in the different applied organic loading rates

Figure 4 shows COD removals higher than those obtained in the systems studied previously, in which OLR of 0.2 $\mathrm{kg}_{\text {COD }} \mathrm{m}^{-3} \mathrm{~d}^{-1}$, average removals ranged from 8 to $32 \%$ COD. In this load, with 32 days of operation and HRT of 1.75 $d$, average removals varied from 38 to $43 \%$ with or without the addition of spongy support, similar to that observed in Welander et al. (1997) in a pilot scale aerated lagoon treating cellulose effluent [24]. With the increase of the load to $0.6 \mathrm{~kg}_{\mathrm{COD}} \mathrm{m}^{-3} \mathrm{~d}^{-1}$, from 33 to 47 days of operation and HRT of $0.45 \mathrm{~d}$, COD removal remained above $30 \%$, still lower than AL without APG of Machado (2017) that obtained an average COD removal of $47.3 \%$ for the same applied organic load rate [33].
In $1.2 \mathrm{~kg}_{\mathrm{COD}} \mathrm{m}^{-3} \mathrm{~d}^{-1}$, there was a recovery in the system regarding the removal of the organic matter from the Kraft pulp mill effluent, reaching values close to $50 \%$ higher than those observed for the same effluent in the same OLR $[12,16]$. In this stage, with 48 to 61 days of operation and HRT of $0.65 \mathrm{~d}$, despite to the effluent used presented higher recalcitrance (sample 5), colour, TPC and lignin derivatives (Table 3 ) in this condition, which may indicate was achieved the best [12].

Still in Figure 4, regarding $\mathrm{BOD}_{5}$, it was observed that, in OLR $0.2 \mathrm{~kg}_{\mathrm{COD}} \mathrm{m}^{-3} \mathrm{~d}^{-1}$, with and without APG, there was a $\mathrm{BOD}_{5}$ removal of $80 \%$, in OLR $0.6 \mathrm{~kg}_{\mathrm{COD}} \mathrm{m}^{-3} \mathrm{~d}^{-1}$ $\mathrm{BOD}_{5}$ removal declined to $62 \%$, still within the expected for aerated lagoon systems [4]. For OLR $1.2 \mathrm{~kg}_{\mathrm{COD}} \mathrm{m}^{-3} \mathrm{~d}^{-1}$, the $\mathrm{BOD}_{5}$ removal reached values close to $80 \%$, as in the lowest loading.

Colour removal was not verified during the treatment for sample 4, with an increase up to loading $0.6 \mathrm{~kg}_{\mathrm{COD}} \mathrm{m}^{-3}$ $\mathrm{d}^{-1}$. According to Milestone et al. (2004), aerated lagoons are systems in which there can be a colour generation in pulp mill effluent [28]. As for OLR $1.2 \mathrm{~kg}_{\mathrm{COD}} \mathrm{m}^{-3} \mathrm{~d}^{-1}$. a colour removal of about $20 \%$ was observed, that goes against moving bed biofilm treatment systems in the same organic load rate $[12,16]$. The color formation can occur due to the low HRT and the high aeration to maintain support media on movement preventing the biotransformation of the macromolecules that generating colour [16]. 
Table 4 Comparison of average ANOVA - Tukey* of aerated lagoon with spongy support

\begin{tabular}{|c|c|c|c|c|c|c|c|}
\hline \multirow{2}{*}{$\begin{array}{l}\mathrm{ORL} \\
\left(\mathrm{kg}_{\operatorname{COD}} \mathrm{m}^{-3} \mathrm{~d}^{-1}\right)\end{array}$} & \multicolumn{7}{|c|}{ Physical-chemical parameters } \\
\hline & COD & $\mathrm{BOD}_{5}$ & Colour & TPC & $\begin{array}{l}\text { Aromatic } \\
\text { compounds }\end{array}$ & $\begin{array}{l}\text { Lignin } \\
\text { derivated } \\
\text { compounds }\end{array}$ & $\begin{array}{l}\text { Ligno- } \\
\text { sulfonic } \\
\text { compounds }\end{array}$ \\
\hline 0.2 & $42.6 \mathrm{ab}$ & $83.4 \mathrm{a}$ & $0.4 \mathrm{~b}$ & $-84 \mathrm{~b}$ & $0.4 \mathrm{~b}$ & $0.2 \mathrm{~b}$ & $5.2 b$ \\
\hline $0.2+A P G$ & $37.9 \mathrm{ab}$ & $82.6 \mathrm{a}$ & $1.2 \mathrm{bc}$ & $-115 c$ & $1.2 \mathrm{bc}$ & $-18.6 b$ & $-12.3 b$ \\
\hline $0.6+A P G$ & $32.2 \mathrm{~b}$ & $62.4 \mathrm{~b}$ & $-21.9 c$ & $-89 b c$ & $-21.9 c$ & $-9.5 b$ & $-17.3 b$ \\
\hline $1.2+A P G$ & $49.5 \mathrm{a}$ & $75.9 a$ & $18.1 \mathrm{a}$ & $17.7 \mathrm{a}$ & $18.1 \mathrm{a}$ & $21.7 \mathrm{a}$ & $11.6 \mathrm{a}$ \\
\hline
\end{tabular}

*Equivalent letters, samples of the same group with no significant difference between means ( $>0.05$ ), different letters, groups with significant different means ( $p<0.05$ ).

Regarding total phenolic compounds, the treatment showed a profile of TPC increase in AL-APG, up to loading $0.6 \mathrm{~kg}_{\mathrm{COD}} \mathrm{m}^{-3} \mathrm{~d}^{-1}$, from $84 \%$ until $115 \%$. In these cases, the TPC increases in the treated effluent was attributed to the oxygenation of the system to keep the support media suspended (Dissolved oxygen $>4 \mathrm{mg} \mathrm{L}^{-1}$ ). This oxidant environment allows the fragmentation of macromolecules of lignin in compounds smaller and more stable with aromatic nature such as phenolic derivatives [30]. As for the last loading, $1.2 \mathrm{~kg}_{\mathrm{COD}} \mathrm{m}^{-3} \mathrm{~d}^{-1}$, and HRT reduction from 1.7 to $0.7 \mathrm{~d}$, this fragmentation of molecules may have not been favored. In this case, an average removal of $18 \%$ was verified, a value higher than the control lagoon of Machado et al. (2018) and the MBBR of Vanzetto et al. (2014) and Peitz and Xavier (2017), both treating Kraft pulp mill effluent in the same organic load rate $[12,13,16]$.

As for compounds derived from lignin, from the beginning in the ORL $0.2 \mathrm{~kg}_{\mathrm{COD}} \mathrm{m}^{-3} \mathrm{~d}^{-1}$ without APG had removal of the aromatic $\left(U V_{254 n m}\right)$, ligninic $\left(U V_{280 n m}\right)$ and lignosulfonic $\left(U V_{346 n m}\right)$ compounds; however, the increase of these compounds in the treated effluent became frequent, lasting up to organic load rate $0.6 \mathrm{~kg}_{\mathrm{CoD}} \mathrm{m}^{-3} \mathrm{~d}^{-1}$. In the last phase of the treatment, OLR $1.2 \mathrm{~kg}_{\mathrm{COD}} \mathrm{m}^{-3} \mathrm{~d}^{-1}$, with lowest biodegradability ratio, the system presented removals around $20 \%$ of the lignin derivatives, higher than aerated lagoon with removal around 3\% [33]. It was associated with the biotransformation of lignin macromolecules, repolymerizing them and forming new chromophores during biological treatment by aerated lagoons [28]. There was a removal only in this condition, all compounds derived from lignin $\left(U V_{254 n m} ; U_{280 n m} ; U_{346 n m}\right)$ presented removals above $10 \%$. The $\mathrm{UV}_{254 \mathrm{~nm}} / \mathrm{UV}_{280 \mathrm{~nm}}$ ratio indicated predominance of aromatic compounds in the effluent in different applied loadings, the obtained values were between 1.15 to 1.32 .

Regarding the acute ecotoxicity, no acute effect was observed in both the influent and the effluent of the $A L-A P G$ system at the organic loads evaluated. TF $=1$ was obtained for all samples tested. The biotransformations that could have occurred during the AL-APG treatment did not increase the acute ecotoxicity of the compounds present in the medium, so there was no change in the Toxicity Factor.

About the biomass results, this was preferentially concentrated in the mixed liquor. VSS concentrations varied from 530 to $3070 \mathrm{mg} \mathrm{L}^{-1}$. Regarding the VSS/TSS ratio for suspended solids, the values obtained were 0.10 in the first stage, corresponding to an older and stabilized sludge with little active biomass [17]. This ratio increased to 0.35 with the addition of APG, reaching 0.54 in OLR $0.6 \mathrm{~kg}_{\mathrm{COD}} \mathrm{m}^{-3} \mathrm{~d}^{-1}$ and 0.59 for the load $1.2 \mathrm{~kg}_{\mathrm{COD}} \mathrm{m}^{-3} \mathrm{~d}^{-1}$, showing growth of biomass and the importance of its adaptation time. With respect to adhered biomass, VSS concentrations from raised up 4 to $547 \mathrm{mg} \mathrm{L}^{-1}$.

With the data presented in Figure 4, the average values of the aerated lagoon with spongy support with load variation were evaluated in order to verify differences between the organic load rates applied and the system performance in the removal of the physical - chemical parameters. For this, ANOVA - Tukey test was applied, after checking the normality of the data and its results are present in Table 4.

It was possible to verify that only differences between the

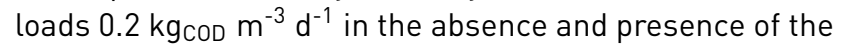
support media for the TPC's average were verified. It was also possible to verify that the OLR $1.2 \mathrm{~kg}_{\mathrm{COD}} \mathrm{m}^{-3} \mathrm{~d}^{-1}$ was the one that presented significant difference of the other loads in all physical-chemical parameters, being this the best condition for the treatment of the studied Kraft pulp mill effluent.

Despite of this observation, the OLR of $1.2 \mathrm{~kg}_{\mathrm{COD}} \mathrm{m}^{-3}$ $d^{-1}$ and HRT of $0.7 d$ were about 6 times higher than those typically employed on aerated lagoon industrial systems.

\section{Conclusion}

In this work, the effects of the APG arrangements modifying aerated lagoons and the performance of these AL-APG systems in different OLR applied to Kraft pulp mill effluent were evaluated. The AL-APG systems in the free 
and confined modalities presented removal above $50 \%$ and $30 \%$ for $\mathrm{BOD}_{5}$ and $\mathrm{COD}$, respectively and an increase in total phenolic compounds and lignin derivatives. This implies in increasing the effluent recalcitrance and, consequently, negative effects for these discharges on aquatic environment. The treatment in the aerated lagoons operating in the OLR $0.2 \mathrm{~kg}_{\mathrm{COD}} \mathrm{m}^{-3} \mathrm{~d}^{-1}$ with the free and confined media did not present significant differences between them. They had worse performance than a control lagoon, so, these modifications are not indicated to treat pulp and mill effluent considering low OLR usually applied by industry.

The best performance of $A L-A P G$ was observed for the OLR $1.2 \mathrm{~kg}_{\text {COD }} \mathrm{m}^{-3} \mathrm{~d}^{-1}$ with APG. The COD and $\mathrm{BOD}_{5}$ removals were, on average, $50 \%$ and $75 \%$, respectively and the removal of lignin derived compounds and total phenolic compounds was verified for this organic load rate, corroborating with were observed in others biological treatment of moving bed in similar OLR.

On acute ecotoxicity in Daphnia magna, this was removed in all samples treated by AL-APG. With this, it can be verified that this proposed modification for aerated lagoons is indicated for plants or treatment units already implanted, but there was increased demand to treat pulp mill effluent in shorter hydraulic retention times. The biomass was concentrated in the mixed liquor and showed development and stabilization.

It is suggested to apply the spongy support media in organic loads of the order of $1.2 \mathrm{~kg}_{\mathrm{COD}} \mathrm{m}^{-3} \mathrm{~d}^{-1}$, which are larger than those typically used in aerated lagoons. Besides it would comply with organic matter release criteria $\left(\mathrm{BOD}_{5}\right)$ and further promote the removal of color, TPC and lignin derivatives.

\section{Acknowledgments}

The authors are thankful for the support from the pulp industry which provided the effluent for our study, to the Graduated Program in Environmental Science and Technology, Technological Federal University - Paraná and to all other collaborators.

\section{References}

[1] R. Toczytowska, "Limits and perspectives of pulp and paper industry wastewater treatment - a review," Renewable and Sustainable Energy Reviews, vol. 78, pp. 764-772, Oct. 2017.

[2] M. Kamali and Z. Khodaparast, "Review on recent developments on pulp and paper mill wastewater treatment," Ecotoxicology and Environmental Safety, vol. 114, pp. 326 - 342, Apr. 2015.

[3] L. . M. Subashini, "Review on biological treatment processes of pulp and paper industry waste water," International Journal of Innovative
Research in Science, Engineering and Technology, vol. 4, no. 5, pp. 3721-3725, May 2015.

[4] N. K. Swamy, P. Singh, and I. P. Sarethy, "Aerobic and anaerobic treatment of paper industry wastewater," Research in Environment Life and Science, vol. 4, no. 4, pp. 141-148, 2011.

[5] D. V. 0 de Minegatti, "Caracterização dos parâmetros de controle e avaliação de desempenho de um reator biológico com leito móvel (mbbr)," M.S. tese, Pósgraduação De Engenharia, Universidade Federal Do Rio De Janeiro, Rio De Janeiro, Brasil, 2008.

[6] J. C. Leyva, J. Martín, and J. M. Poyatos, "Moving bed biofilm reactor to treat wastewater," International Journal of Environmental Science and Technology, vol. 14, no. 4, pp. 881-910, Apr. 2017.

[7] M. Rodgers and X. M. Zhan, "Moving-medium biofilm reactors," Reviews in Environmental Science and Biotechnology, vol. 2, no. 2-4, pp. 213-224, Jun. 2003.

[8] F. Y. Fujii, "Análise comparativa entre o processo de lodo ativado e o reator de biofilme de leito móvel na remoção de nitrogênio de esgoto sanitário," M.S. thesis, Escola Politécnica da Universidade de São Paulo, São Paulo, Brazil, 2011.

[9] K. C. Cheng and A. D. and, "Advances in biofilm reactors for production of value-added products," Appl. Microbiol. Biotechnol., vol. 87, no. 2, pp. 445-56, Jun. 2010.

[10] H. Sakuma, "Paper mill wastewater treatment by moving bed biofilm reactor using sponge media," Japan Tappi Journal, vol. 58, no. 10, pp. 1361-1365, 2004.

[11] V. Raandel and J. V. Der Lubbe, Handbook of Biological Wastewater Treatment: Design and Optimisation of Activated Sludge Systems, 2nd ed. Londres, Inglaterra: IWA Publishing, 2012.

[12] S. C. Vanzetto, M. Klenk, S. M. C. Rosa, and C. R. Xavier, "Tratamento de efluente de indústria de papel e celulose por reator mbbr," Hydro, no. 89, pp. 42-45, Mar. 2014.

[13] E. P. Machado, C. R. Xavier, and G. H. Couto, "Tratamento de efluente kraft em lagoa aerada facultativa empregando enzimas lignolíticas," Interciencia, vol. 43, no. 8, pp. 590-596, 2018.

[14] C. R. Costa, P. Olivi, C. M. R. Botta, and E. L. G. Espindola, "A toxicidade em ambientes aquáticos: discussão e métodos de avaliação," Química Nova, vol. 31, no. 7, pp. 1820-1830, 2008.

[15] T. Furley, F. Mello, and J. B. L. Siqueira, "Principais questões ambientais causadas pelos efluentes de fábricas da américa latina," O papel, vol. 79, no. 4, pp. 70-77, 2018.

[16] C. Peitz and C. R. Xavier, "Tratamento de efluente kraft contendo fitoesteróis por reator de leito móvel mbbr," Interciencia, vol. 42, pp. 536-541, Aug. 2017.

[17] M. von Sperling, Introdução à qualidade das águas e ao tratamento de esgotos, 4th ed. Gerais, Brasil: Belo Horizonte, 2014.

[18] E. W. Rice, R. B. Baird, A. D. Eaton, and L. S. Clesceri, Standard Methods for the Examination of Water and Wastewater, $22^{\circ}$ ed., 22nd ed. Washington, USA: American Public Health Association - APHA, 2012.

[19] S. Chamorro and et al., "Removal of stigmasterol from kraft mill effluent by aerobic biological treatment with steroidal metabolite detection," J Environ Sci Health A Tox Hazard Subst Environ Eng., vol. 51, no. 12, pp. 1012-1017, Oct. 2016.

[20] R. Lewis and et al., "Study of the impacts of process changes of a pulp and paper mill on aerated stabilization basin (asb) performance," Chemosphere, vol. 211, pp. 767-774, Nov. 2018.

[21] Ecotoxicologia aquática - Toxicidade aguda - Método de ensaio com Daphnia spp (Crustacea, Cladocera), ABNT NBR12713, 2016.

[22] Teste de tukey. CCA entro de Ciências Agrárias. Accessed Oct. 10, 2018. [Online]. Available: https://www.cca.ufscar.br/pt-br/servicos/ teste-de-tukey

[23] M. A. Hubbe and et al., "Wastewater treatment and reclamation: A review of pulp and paper industry practices and opportunities," Bioresources, vol. 11, no. 3, pp. 7953-8091, 2016.

[24] T. Welander, A. Löfgvist, and A. Selmer, "Upgrading aerated lagoons at pulp and paper mills," Water Science and Technology, vol. 35, no. 2, pp. 117-122, 1997, forest Industry Wastewaters V.

[25] C. M. Dykstra, H. D. Gilesa, S. Banerjeeb, and S. G. Pavlostathis, "Fate and biotransformation of phytosterols during treatment of pulp and paper wastewater in a simulated aerated stabilization 
basin." Water. Res., vol. 68, pp. 589-600, Jan. 2015.

[26] M. Belmonte and et al., "Improved aerobic biodegradation of abietic acid in ecf bleached kraft mill effluent due to biomass adaptation," J. Hazard. Mater., vol. 135, no. 1-3, pp. 256-63, Jul. 2006.

[27] R. Lewis, J. A. V. Leeuwen, C. W. K. Chow, A. Everson, and D. M. Lewis, "Assessment of coagulated and non-coagulated asb performance used to treat pinus radiata sulfite pulp and paper mill effluent by resin fractionation and hpsec techniques," Chemical Engineering Journal, vol. 213, pp. 109-117, 2012.

[28] C. B. Milestone, R. R. Fulthorpe, and T. R. Stuthridge, "The formation of colour during biological treatment of pulp and paper wastewater," Water. Sci. Technol, vol. 50, no. 3, pp. 87-94, 2004.

[29] R. Lewis and et al., "Changes in the organic character of post-coagulated pinus radiata sulfite pulp mill wastewater under aerated stabilization basin treatment-a laboratory scale study," Chemical Engineering Journal, vol. 175, pp. 160-168, Nov. 2011.
[30] W. S. Wahyudiono, M. Sasaki, and M. Goto, "Recovery of phenolic compounds through the decomposition of lignin in near and supercritical water," Chemical Engineering and Processing: Process Intensification, vol. 47, no. 9-10, pp. 1609-1619, Sep. 2008.

[31] F. Çeçen, "The use of uv-vis measurements in the determination of biological treatability of pulp bleaching effluents," in $7^{\text {th }}$ International Water Association Symposium on Forest Industry Wastewaters, Seattle, USA, 2003, pp. 135-142.

[32] T. H. Furley, "Identificação da causa da toxicidade de efluentes de fábricas de celulose e papel da américa latina," Revista 0 Papel, pp. 34-42, Mar. 2009.

[33] E. P. Machado, "Tratabilidade de efluente kraft por processo biológico facultativo assistido com enzimas lignolíticas," M.S. thesis, Universidade Tecnológica Federal do Paraná, Curitiba, Brasil, 2017. 